\title{
Standardization and Preparation of Guava Cheese from Different Cultivars
}

\author{
Rashmi Shukla ${ }^{1 *}$, Y.K. Shukla ${ }^{1}$ and Smita Pathak ${ }^{2}$ \\ ${ }^{1}$ Krishi Vigyan Kendra, B.M.College of Agriculture, Khandwa (M.P.), India \\ ${ }^{2}$ Govt. Home Science College, Jabalpur (M.P.), India
}

*Corresponding author

\begin{tabular}{|c|c|}
\hline & A B S T R A C T \\
\hline $\begin{array}{l}\text { Reducing sugar, Non } \\
\text { reducing sugar, } \\
\text { Physicochemical, } \\
\text { Nutritional, Sensory, } \\
\text { Titrable acidity }\end{array}$ & \multirow{3}{*}{$\begin{array}{l}\text { In present investigation, the influence of processing on the physicochemical and nutritional } \\
\text { composition of Guava product was evaluated. Guava cheese was prepared from fresh } \\
\text { guava fruits adding and without adding milk powder. The physicochemical parameters of } \\
\text { fresh guava fruits were evaluated like pH, total soluble solids and titratable acidity along } \\
\text { with calcium, phosphorus magnesium and Iron content before conduction experiments. } \\
\text { After preparation of guava cheese proximate analysis of the product were also analyzed } \\
\text { like total sugar, reducing sugar and non-reducing sugar vitamin C, protein, fat and fiber. } \\
\text { The organolaptic study was performed on } 9 \text { point hedonic scale on ISI (1971). In our } \\
\text { findings cheese of guava may be proponed with the use of verity L- } 49 \text { pulp and milk } \\
\text { powder. L- } 49 \text { is the best variety for cheese preparation. The variety can be used for } \\
\text { processing propose at domestic as well as commercial. }\end{array}$} \\
\hline Article Info & \\
\hline $\begin{array}{l}\text { Accepted: } \\
\text { 07 February } 2018 \\
\text { Available Online: } \\
10 \text { March } 2018\end{array}$ & \\
\hline
\end{tabular}

\section{Introduction}

Guava (Psidium guajava L.) is delicious fruit of the plant family Myrtaceae. It is a popular tree fruit of the Asian Subcontinent, it is commonly known as "Apple of Tropics" and locally by different names Such Amrud, Peru, Piyara Koyyya. Sedepandu, etc. Guava is valued as a Potential Source of pectin, ascorbic acid (Vitamins -c), Sugars and minerals (Harmanan et al., 2005), Guava is popular among the people of all social strata due to its comparative low price than some other fruits nourishing value and good taste.

Value addition of fruit crops to produces food products free from unwanted production and transform it in to more useful from one fresh product. Demand of the preserved product $\mathrm{s}$ is increased enormously in the country day by day. It is an urgent need to pay more attention on the processing of guava fruit as well as the production of acceptable products, so that the growers may get remunerative prices and consumers get more opportunity to enjoy the taste of guava in the form of the food products.

Guava fruits are utilized for production of their byproduct like jam, jelly, pulp puree, toffee, leather, juice, baby food, beverage base, syrup and wine (Lal et al., 1998, Jain and Asati, 2004). Apart from these products, guava pulp is also being used for preparation 
of new product like cheese. It has been observed that consumer's taste to words the consumption of regular Jam, Jelly, paste and puree changing with modern products. The fruit cheese or cheese like products is gaining importance in National and International market.

\section{Materials and Methods}

In the present investigation three cultivars of guava Viz. L -49 Allahabad Safeda and apple guava were obtained from the guava orchards of fruit Research farm Imalia, J.N.K.V.V. Jabalpur (M.P.) for preparation of guava cheese. Two types of cheese were prepared from guava one with milk powder and other without adding milk powder using the method suggested by. Besides, physicals properties of guava fruits was Rangannna (1997) for various constituents viz. weight, length Diameter, Specific gravity, acidity, $\mathrm{pH}$, ascorbic acid, fiber, TSS, Reducing Sugar, non-Reducing sugar and total sugar. The Proximate analysis, moisture, protein, fat Reducing Sugar, non-reducing Sugar, total Sugar, Fiber, ash and minerals using AoAc(1992).

The organoleptic evaluation for the trails viz. Color, Flavor texture, taste and over all acceptability of guava cheese was also carried out for both types of cheese made of three cultivars. The various organoleptic quality attributes were estimated by the method discussed by Amerine et al., (1965). The data obtained was analyzed statistically for analysis of variance in a completely randomized design Panshe and Sukhatme (1963.)

\section{Results and Discussion}

\section{Physical properties of fresh guava fruits}

The physical properties viz., fruit weight, fruit length, diameter and specific gravity of guava were recorded before processing Figure 1 and 2. The variety Allahabad safeda exhibited maximum values of weight $(220.0 \mathrm{~g})$, length $(17 \mathrm{~cm})$, diameter $(7.16 \mathrm{~cm})$ and specific gravity $(1.23 \%)$ superior over both the varieties Lucknow-49 and Apple guava. The variation in fruit size of varieties is mainly due to the genetic characteristics of the variety. Singh (1988) reported that the variation in size of fruit may be due to the number and size of seeds exit in the fruit. More number and size of seeds ultimately increase the fruit size. Dubey et al., (2009) also reported that the Allahabad safeda possessed the higher fruit weight.

\section{Chemical composition of guava fruits pulp}

The guava pulp of different varieties used for preparation of cheese were evaluated Figure 3 to 6 for ascorbic acid, pectin, fibre, acidity and $\mathrm{pH}$ and found that acidity of the fruit to be varied significantly with respect to varieties. However, $\mathrm{pH}$ did not affect significantly. The maximum percent of acidity $(0.43 \%)$ was recorded in variety Lucknow-49 closely followed by Allahabad safeda. Value of $\mathrm{pH}$ of the guava fruit observed to be $4.23,4.16$ and 4.13 for the Lucknow-49; Allahabad safeda and Apple guava cultivars shows no significant difference for each other.

The ascorbic acid content ranged from 236.32 - $246.51 \mathrm{mg} / 100 \mathrm{~g}$. The maximum ascorbic acid content was observed in Lucknow-49 $(246.51 \mathrm{mg} / 100 \mathrm{~g})$ followed by Allahabad safeda $(244.87 \mathrm{mg} / 100 \mathrm{~g})$ The pectin content was observed in the range of 1.08-1.23 percent for different varieties. Maximum pectin content of $1.23 \%$ was observed for variety Lucknow-49 followed by Allahabad safeda $(1.18 \%)$

The fiber content, varied from 4.22-4.90 percent under different varieties of guava. Maximum fiber content was observed with 
Variety Lucknow-49 (4.90\%) followed by Apple guava (4.84\%) and proved significantly superior over Allahabad safeda. These findings are in closed with the findings of Khattak (1997) and Kalloo (2005).

Total soluble solids recorded in the range of $12.76-13.32$ percent for different varieties of guava. Maximum value was observed for Lucknow-49 (13.32\%) which was higher over to Apple guava (12.76\%)

Reducing sugar, non-reducing sugar, and total sugar were in the range of 4.00-4.30, 3.073.50 and 7.70-8.22 percent for different varieties of guava. The variety Lucknow-49 recorded the maximum content of nonreducing and total sugar and proved superior. The above finding shows that the variety Lucknow-49 is the best with respect to quality constituents required for making cheese.

The variation in the chemical constituents among the varieties due to the variation in the heredity characters as well as the agro climatic situations like temperature, humidity, soil type, supply of nutrients and water, at growth and development of fruits. Pandey et al., (1997) reported that the size and weight of different varieties were positively associated with each other for total soluble solids, reducing, non-reducing and total sugars.

The fruits of variety Lucknow - 49 and Allahabad safeda were found to be at par to each other in term of ascorbic acid content whereas Lucknow 49 proved to be superior over Allahabad safeda and Apple guava with respect to pectin and fiber.

The characteristics of guava cultivars Lucknow-49 described by Harmanan et al., (2005) and Alizai (2007) and narrated that cultivar Lucknow-49 and Allahabad safeda are quite different for content of pectin and fiber as well as minerals.

\section{Chemical constituents in prepared guava cheese}

Chemical constituents were analysed of prepared guava cheese for qualitative studies Table 1 and 2. Effect on protein content the analysis of variance revealed that the different varieties and addition of milk powder had significant. The interactive effect of both the factors was also significant. As regards to the variety used for the preparation of cheese found to be significantly differ with each other and Lucknow-49 proved to be the best and recorded maximum protein content of 1.67 per cent. The use of milk as additive also significantly increased the protein content of cheese over without milk powder. The combination of guava variety and milk powder (Lucknow-49 with milk powder) recorded the maximum value of $2.36 \%$ protein which was significantly higher over rest other combinations. It was also noted that all the varieties positively increased the protein content with the inclusion of milk powder in the preparation of cheese over without milk. It is clear from the results that the values of protein just double after use of milk powder over without milk. Milk powder added cheese contents more protein, as milk itself a protein rich source compared while it add to others increased the same as reported by Gupta et al., (2011).

Varieties of guava not showed any significant change in fat content of cheese. However, the milk powder significant effect on fat content. The samples of guava cheese with milk powder contain $2.07 \%$ fat. The Lucknow-49 variety with milk powder noted the maximum fat content i.e. $2.12 \%$. These findings clearly indicated that the milk powder has efficiency to sorting out significant positive change in content of fat in guava cheese. The milk powder when used as additive for the preparation of guava cheese for enrichment of fat percent for 1.44 to 2.07 . This is might be 
due to stronger casein bound curd structure formed from milk that probably led to better fat retention Patil et al., (2009).

Content of reducing sugar in cheese Variety Lucknow-49 used for preparation of cheese contains higher (37.50\%) reducing sugar followed by Allahabad safeda with $36.48 \%$. Use of milk powder shows significant change in reducing sugar content of cheese. Maximum reducing sugar (38.86\%) was observed in the Allahabad safeda variety.

Non reducing sugar content in varieties and milk powder significantly changed the constituent of cheese amongst the varieties Lucknow-49 possessed the maximum value $(32.48 \%)$ which was significantly superior over Apple guava. However, the variety Allahabad safeda and apple guava showed no significant difference from each other with respect to non-reducing sugar in cheese. The significant change in per cent non reducing sugar in cheese due to addition of milk powder. The interaction of variety and milk powder was also significant. The maximum content of $33.78 \%$ was noted with the use of pulp of variety Locknow-49 with addition of milk powder.

Total sugar content in guava cheese significantly varied due to varieties. The Lucknow-49 had potential to contribute significantly higher total sugar in cheese. The variety Allahabad safeda $(67.46 \%)$ which was significantly superior to Apple guava (64.61\%) but inferior to Lucknow-49 with respect to content of total sugar. The milk powder also had the significant effect on the content of total sugar in cheese. The milk powder added product noted to contain (70.59\%) significantly higher total sugar over without milk powder cheese.

The results reported in the foregoing had reveal that the reducing sugar, non-reducing sugar and total sugar increased with the addition of milk powder as compared to guava cheese prepared without milk powder. The relative increase in reducing sugar, nonreducing sugar and total sugar content in the cheese due to milk powder application may be attributed to direct addition of sugars through milk powder. The results are also in the same pattern with the finding of Kumar et al., (2009).

The fibre content revealed that neither variety nor milk powder found to exhibited change in content of fiber in cheese. The varieties Allahabad safeda proved to be better as it possessed less fiber content $(4.0 \%)$ followed by Apple guava (4.36\%) and Lucknow-49 $(4.42 \%)$. Similarly, use of milk powder slightly reduced the fiber percentage in cheese and recorded $4.19 \%$ fibre whereas without milk powder noted the $4.93 \%$ fiber in cheese. The interaction was also found to be nonsignificant. Thus from the findings it could be concluded that neither variety nor use of milk powder as additive unable to change the content of fiber in cheese. The reduction in fiber content in milk added cheese is due to the fact that milk powder increase the carbohydrate and moisture content (Ashaye et al., 2005).

Ash content in cheese significantly changed due to varieties as well as use of milk powder used for preparation of cheese. The pulp of variety Lucknow-49 used for preparation of cheese recorded higher value of ash $(0.76 \%)$ over rest of the varieties. However, the variation between Allahabad safeda and Apple guava were no significant and recorded $0.69 \%$ and $0.68 \%$ ash, respectively.

The milk powder proved efficient to be to bring the significant change in ash content. Milk powder added to product possessed higher value of ash (0.75\%) over $0.67 \%$ recorded under without milk powder. The 
interaction found to be non-significant, though, the higher values of 0.79 was noted in Lucknow-49 along with milk powder. Quality cheese of guava may be prepared with the use of variety Lucknow-49 pulp by mixing of milk powder. These results are in close accordance with the findings of Almedia et al., (2009.)

The prepared cheese was chemically analyzed for various nutrients viz., $\mathrm{Ca}, \mathrm{Mg}, \mathrm{P}$ and $\mathrm{Fe}$. Significant difference exists among the varieties as regards for calcium content. The Apple guava registered the maximum value of $2.05 \mathrm{mg} / 100 \mathrm{gm}$ and was significantly superior over Allahabad safeda. The variations between Lucknow-49 and Allahabad safeda with respect to calcium content were found to be non-significant.

Cheese prepared with the use of milk powder and without milk powder showed marketable variations for calcium content. The use of milk as additive in the preparation of cheese possessed significantly higher content $(2.17 \mathrm{mg} / 100 \mathrm{~g})$ of calcium as compared to without milk powder $(1.51 \mathrm{mg} / 100 \mathrm{~g})$.The statistical analysis of data significant variations in magnesium content in cheese due to varieties as well as use of milk powder as additive. The maximum content of Magnesium $(1.53 \mathrm{mg} / 100 \mathrm{~g})$ was recorded in Allahabad safeda, which was significantly superior over Lucknow-49 but statistically at par to Apple guava. Further, the use of milk powder in the preparation of cheese recorded the significantly higher content of Magnesium $(1.57 \mathrm{mg} / 100 \mathrm{~g}) \quad$ over without milk $(1.17 \mathrm{mg} / 100 \mathrm{~g})$ powder product.

Phosphorus content in guava cheese is significantly influenced by varieties and use of milk powder. The simple and interactive effect of treatment combination was significant. The maximum content of phosphorus $(1.96 \mathrm{mg} / 100 \mathrm{~g})$ was noted in cheese prepared from variety Apple guava which was significantly superior over Allahabad safeda and Lucknow-49 varieties. The use of milk powder for the preparation of cheese as additive bring out the significant change in content of phosphorus content and recorded significantly higher content of $(1.90 \mathrm{mg} / 100 \mathrm{~g})$ as compared to product without milk powder $(1.50 \mathrm{mg} / 100 \mathrm{~g})$. The interactive effect of varieties and additives also showed significant variations in phosphorus content of cheese. The addition of milk powder significantly increased the phosphorus content over without milk powder product with each variety. Maximum phosphorus content $(2.05 \mathrm{mg} / 100 \mathrm{~g})$ in cheese recorded addition of milk powder for Apple guava variety.

Iron content in cheese prepared from different varieties of guava was assessed and analyzed. The statistical analysis of data showed significant effects of different treatments on the product. Different varieties perform differently with respect to content of iron in cheese. The maximum $(185.53 \mathrm{mg} / \mathrm{kg})$ iron content was noted for Allahabad safeda followed by Apple guava $(172.2 \mathrm{mg} / \mathrm{kg})$. Both of these varieties were found to be significantly superior over Lucknow-49 with respect to iron content. Further, the addition of milk powder in the preparation of cheese had significant effect on the iron content. The milk powder added product possessed significantly higher content of iron $(172.37 \mathrm{mg} / \mathrm{kg})$ over without milk powder. The differences for interaction of variety and milk were found to be non-significant. The findings showed that the variety Allahabad safeda with milk powder produced iron enriched cheese.

Different varieties preformed differently with respect to content of phosphorus, calcium, magnesium and iron. The cheese prepared from apple guava had the higher content of phosphorus and calcium. The Allahabad safeda variety is enriched with magnesium and iron content. 
Int.J.Curr.Microbiol.App.Sci (2018) 7(3): 583-595

Table.1 Chemical composition of prepared guava cheese

\begin{tabular}{|l|l|l|l|l|l|l|l|}
\hline Treatments & $\begin{array}{l}\text { Fiber } \\
(\%)\end{array}$ & $\begin{array}{l}\text { Ash } \\
(\%)\end{array}$ & Fat (\%) & $\begin{array}{l}\text { Protein } \\
(\%)\end{array}$ & pH & Acidity (\%) & $\begin{array}{l}\text { Total Soluble } \\
\text { Solids (\%) }\end{array}$ \\
\hline $\mathbf{V}_{\mathbf{1}} \mathrm{T}_{1}$ & 4.50 & 0.72 & 1.50 & 0.98 & 4.01 & 0.38 & 71.26 \\
\hline $\mathbf{V}_{\mathbf{1}} \mathrm{T}_{2}$ & 4.35 & 0.79 & 2.12 & 2.36 & 4.10 & 0.30 & 80.32 \\
\hline $\mathbf{V}_{2} \mathrm{~T}_{1}$ & 4.08 & 0.67 & 1.43 & 0.92 & 4.15 & 0.32 & 71.10 \\
\hline $\mathbf{V}_{2} \mathrm{~T}_{2}$ & 3.92 & 0.71 & 2.09 & 1.95 & 4.30 & 0.29 & 79.96 \\
\hline $\mathbf{V}_{3} \mathrm{~T}_{1}$ & 4.40 & 0.63 & 1.39 & 0.85 & 4.20 & 0.27 & 71.12 \\
\hline $\mathbf{V}_{3} \mathrm{~T}_{2}$ & 4.32 & 0.74 & 2.02 & 1.75 & 4.50 & 0.24 & 77.26 \\
\hline SE \pm Var. & 0.85 & 0.01 & 0.10 & 0.03 & 0.05 & 0.02 & 0.42 \\
\hline Treat. & 0.76 & 0.02 & 0.08 & 0.02 & 0.05 & 0.02 & 0.54 \\
\hline Var. $\mathbf{X}$ Treat. & 1.79 & 0.05 & 0.13 & 0.04 & 0.23 & 0.05 & 0.93 \\
\hline CD 5\% Var. & NS & 0.03 & NS & 0.07 & 1.26 & 0.06 & 1.26 \\
\hline Treat. & NS & 0.07 & 0.23 & 0.06 & 0.13 & 0.05 & 1.58 \\
\hline Var. X Treat. & NS & NS & NS & 0.11 & NS & NS & NS \\
\hline
\end{tabular}

Table.2 Chemical Composition of prepared guava cheese

\begin{tabular}{|c|c|c|c|c|c|c|c|c|}
\hline Treatments & $\begin{array}{l}\text { Calcium } \\
\text { mg/100 g }\end{array}$ & $\begin{array}{l}\text { Magnesium } \\
\mathrm{Mg} / 100 \mathrm{~g}\end{array}$ & $\begin{array}{l}\text { Phosphorus } \\
\text { Mg/100g }\end{array}$ & \begin{tabular}{|l|} 
Iron \\
Mg/100 g
\end{tabular} & $\begin{array}{l}\text { Ascorbic } \\
\text { acid } \\
\text { Mg/100 g }\end{array}$ & $\begin{array}{l}\text { Reducing } \\
\text { sugar } \\
(\%)\end{array}$ & $\begin{array}{l}\text { Non } \\
\text { reducing } \\
\text { Sugar }(\%)\end{array}$ & $\begin{array}{l}\text { Total } \\
\text { sugar } \\
(\%)\end{array}$ \\
\hline $\mathrm{V}_{1} \mathrm{~T}_{1}$ & 1.38 & 0.88 & 1.20 & 115.31 & 39.45 & 36.48 & 31.17 & 67.65 \\
\hline$V_{1} T_{2}$ & 2.27 & 1.49 & 1.98 & 135.73 & 35.60 & 38.52 & 33.78 & 72.30 \\
\hline $\mathrm{V}_{2} \mathrm{~T}_{1}$ & 1.40 & 1.37 & 1.43 & 181.72 & 34.07 & 34.10 & 30.28 & 64.38 \\
\hline$V_{2} T_{2}$ & 1.90 & 1.69 & 1.69 & 189.50 & 30.65 & 38.86 & 31.68 & 70.54 \\
\hline$V_{3} T_{1}$ & 1.74 & 1.27 & 1.87 & 152.38 & 32.36 & 32.22 & 28.09 & 60.31 \\
\hline$V_{3} T_{2}$ & 2.36 & 1.52 & 2.05 & 192.02 & 29.50 & 36.12 & 31.94 & 68.92 \\
\hline \multirow{3}{*}{$\begin{array}{l}\text { SE } \pm \text { Var. } \\
\text { Treat. } \\
\text { Var. X } \\
\text { Treat. }\end{array}$} & 0.13 & 0.11 & 0.18 & 8.91 & 1.33 & .47 & 0.57 & 0.64 \\
\hline & 0.21 & 0.09 & 0.10 & 7.28 & 1.02 & .55 & 0.46 & 0.52 \\
\hline & 0.37 & 0.16 & 0.18 & 12.60 & 1.54 & .62 & 0.80 & 0.90 \\
\hline \multirow{3}{*}{$\begin{array}{l}\text { CD 5\% } \\
\text { Var. } \\
\text { Treat. } \\
\text { Var. X } \\
\text { Treat. }\end{array}$} & 0.38 & 0.33 & 0.38 & 26.19 & 3.99 & 1.40 & 1.68 & 1.88 \\
\hline & 0.65 & 0.27 & 0.35 & 21.46 & 3.09 & 1.64 & 1.37 & 1.53 \\
\hline & NS & NS & 0.53 & NS & 4.58 & 1.85 & 2.38 & 2.68 \\
\hline
\end{tabular}


Table.3 Organoleptic evaluation of fresh guava cheese

\begin{tabular}{|l|l|l|l|l|l|}
\hline Treatments & Colour & Taste & Flavour & Texture & $\begin{array}{l}\text { Overall } \\
\text { acceptability }\end{array}$ \\
\hline $\mathbf{V}_{1} \mathrm{~T}_{1}$ & 8.06 & 8.60 & 8.10 & 8.55 & 8.12 \\
\hline $\mathbf{V}_{1} \mathrm{~T}_{2}$ & 7.05 & 8.00 & 7.25 & 6.50 & 7.23 \\
\hline $\mathbf{V}_{2} \mathrm{~T}_{1}$ & 6.95 & 7.90 & 7.80 & 7.20 & 7.35 \\
\hline $\mathbf{V}_{2} \mathrm{~T}_{2}$ & 6.39 & 7.60 & 7.20 & 6.90 & 7.02 \\
\hline $\mathbf{V}_{3} \mathrm{~T}_{1}$ & 8.50 & 8.40 & 8.50 & 7.10 & 8.12 \\
\hline $\mathbf{V}_{3} \mathrm{~T}_{2}$ & 7.30 & 8.20 & 7.50 & 7.0 & 7.50 \\
\hline $\mathrm{SE} \pm$ Var. & 0.15 & 0.19 & 0.15 & 0.14 & 0.16 \\
\hline Treat. & 0.13 & 0.16 & 0.13 & 0.13 & 0.13 \\
\hline Var. X Treat. & 0.21 & 0.27 & 0.64 & 0.23 & 0.22 \\
\hline CD 5\% Var. & 0.45 & 0.57 & 0.45 & 0.41 & 0.47 \\
\hline Treat. & 0.37 & 0.46 & 0.37 & 0.40 & 0.38 \\
\hline Var. X Treat. & 0.63 & $\mathrm{NS}$ & $\mathrm{NS}$ & 0.68 & 0.67 \\
\hline
\end{tabular}

Physical parameters of guava fruits

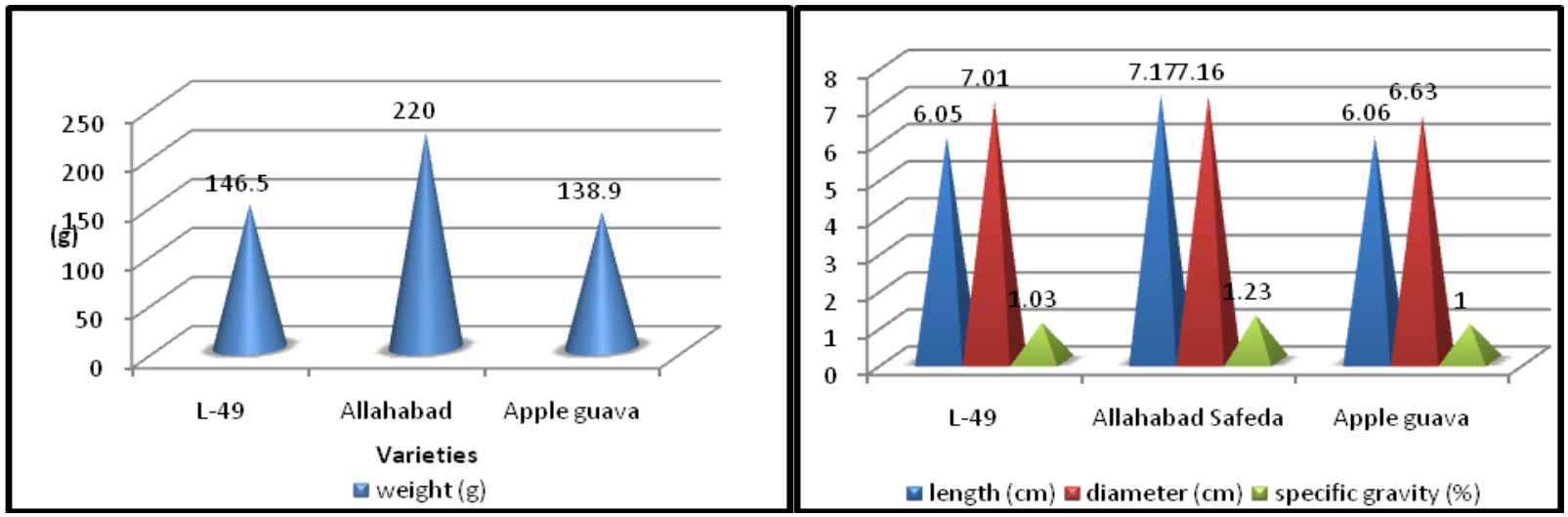

Fig.1

Fig.2

Chemical composition of fresh guava fruit pulp
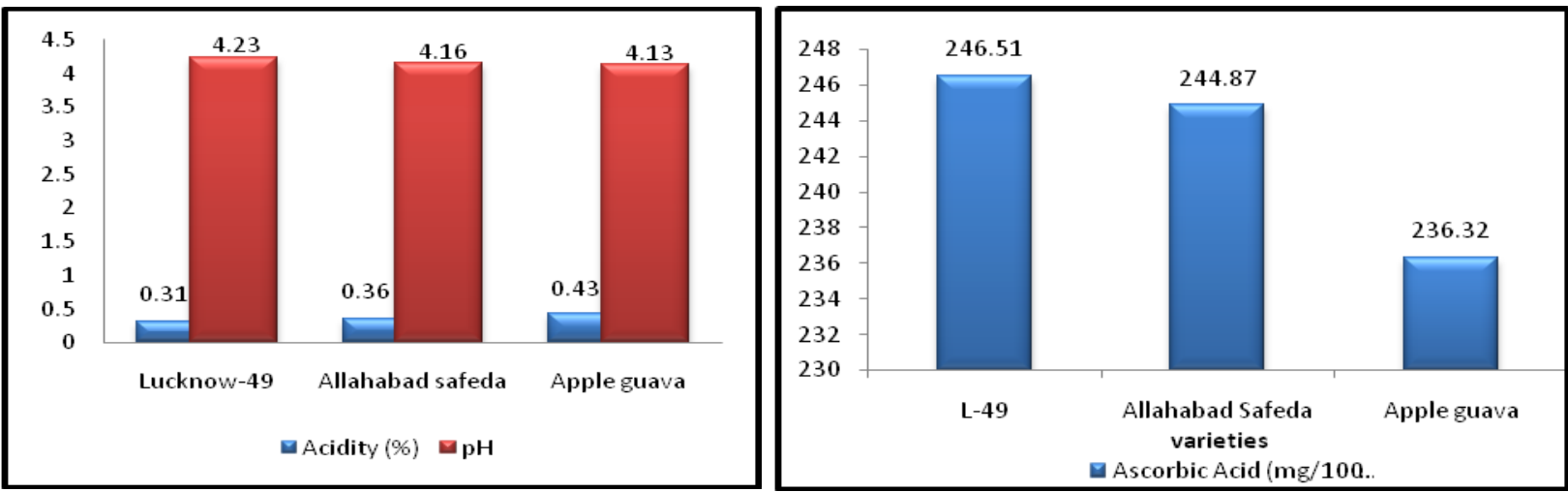
Fig.3

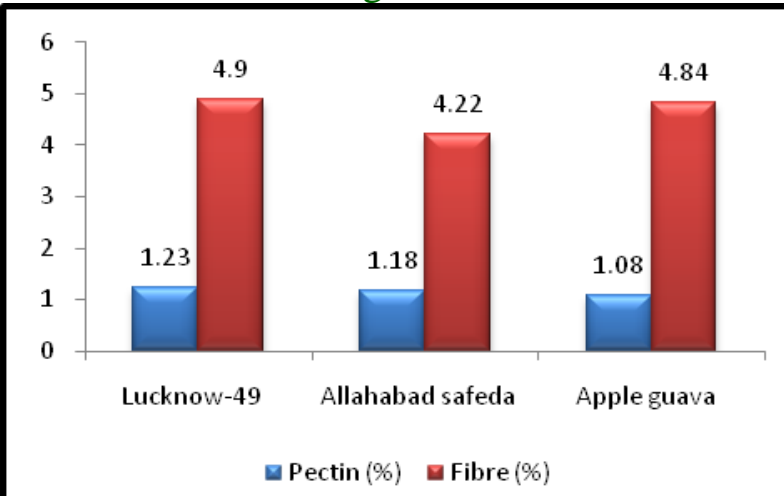

Fig.5
Fig.4

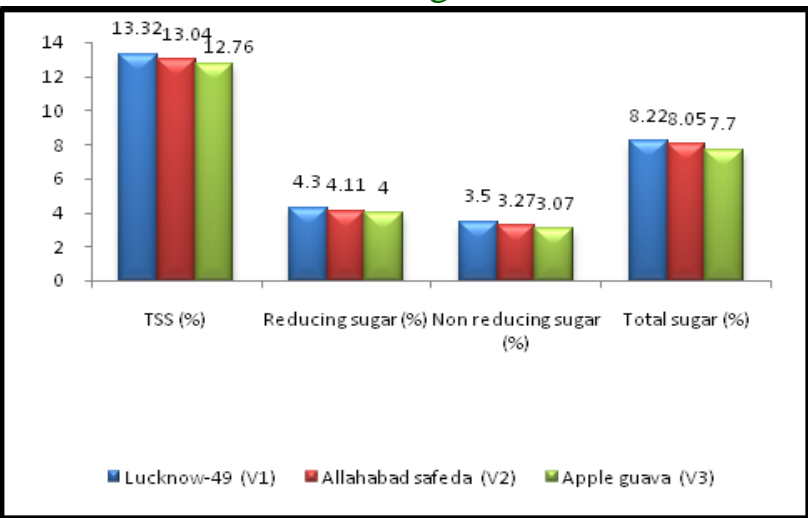

Fig.6

Fig.7 Fresh guava fruits of different varieties and prepared guava cheese with additives

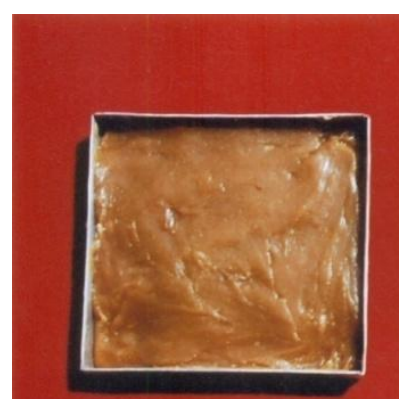

Without milk powder

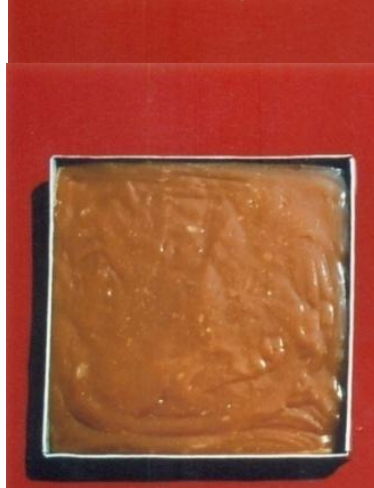

Without milk powder

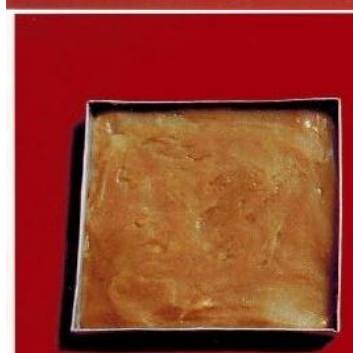

Without milk powder

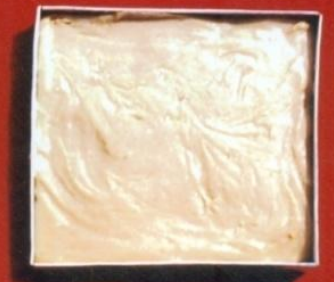

With milk powder

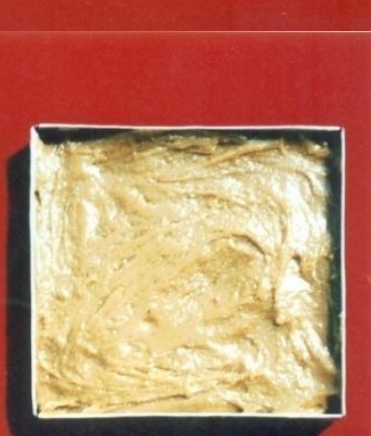

With milk powder

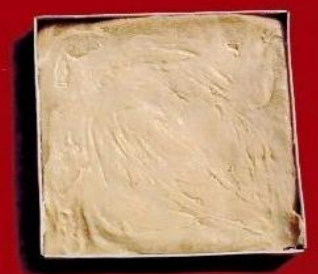

With milk powder

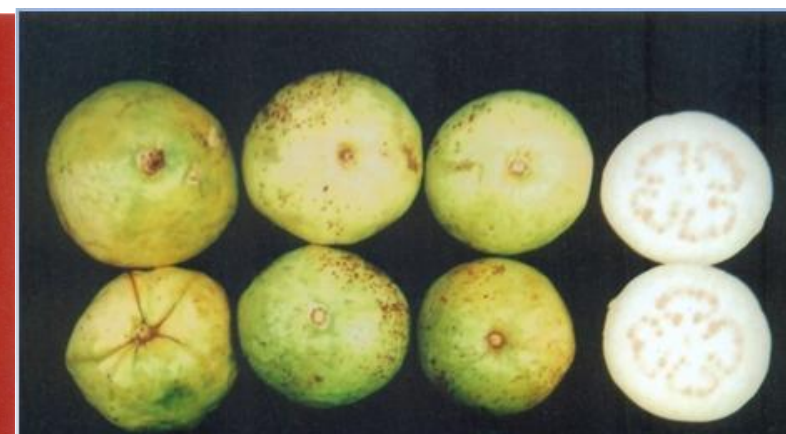

Allahabad safeda
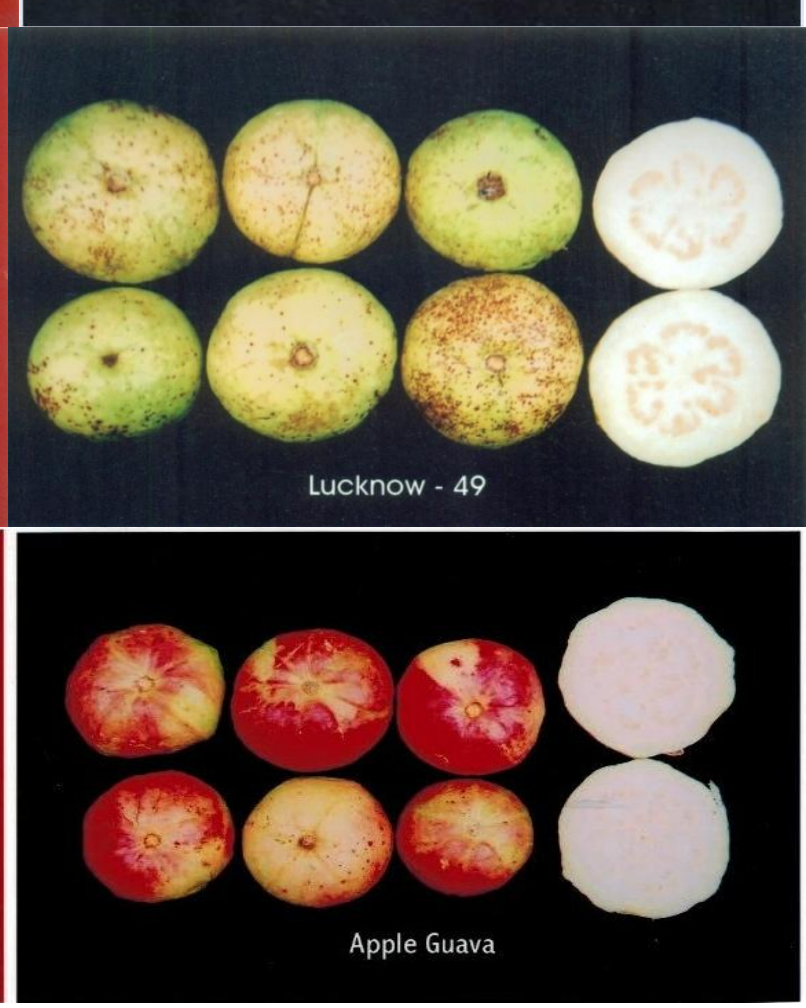
The variations in content of these minerals under different varieties might be due to the chemical composition of variety which changed the content.

In addition of milk powder in cheese had significant effect on the minerals nutrient i.e. Calcium, Magnesium, Phosphorus and Iron content and milk added product possessed significantly higher content of these minerals over without milk powder added treatments in all the varieties used for the preparation of cheese in present experimentation. These findings are in conformity with the findings of Singh et al., (2003) and Durmaz et al., (2006).

This might be due to the fact that milk powder is the main contributing source of minerals apart from the content in pulp of guava. Hence, the increases in minerals (i.e. Calcium, Magnesium, Phosphorus and Iron) content both the addition of milk powder were expected. These finding in cheese are in same pattern with the findings of Chawala et al., (2005).

Significant difference exists for $\mathrm{pH}$ in the prepared product. Cheese prepared from different varieties and use of milk powder. Lucknow-49 recorded lowest $\mathrm{pH}$ of (4.35) followed by Allahabad safeda (4.22) which was significantly superior as compared to Apple guava (4.35) and both were statistically at par from each other. The $\mathrm{pH}$ and acidity both have inverse relationship with each other.

Hence, increase in $\mathrm{pH}$ ultimately decreases in acidity. The findings are in conformity of reports of Torrezan et al., (1999). The change in $\mathrm{pH}$ due to use of milk was also found to be significantly varied and higher $\mathrm{pH}$ of 4.30 was noted for the product contains milk powder. The interaction was found to be nonsignificant. Thus, results showed that the use of milk slightly recharged the $\mathrm{pH}$ of cheese. The results in relation to total soluble solids which showed significant variations of prepared cheese due to varieties and use of milk powder as additive. Variety Lucknow-49 recorded higher values of total soluble solid (75.79\%) closely followed by Allahabad safeda $(75.53 \%)$ and both these varieties proved significant superior to Apple guava. Similar results were also reported by Naikare et al., (1998). The addition of milk powder in the process of cheese making significantly changed the content of total soluble solid and recorded higher $(79.18 \%)$ values. Whereas, without milk powder noted only 71.16 percent total soluble solid which is significantly lower to additives? This may be due to the fact that milk powder is the main contributing source of total soluble solid (Total Soluble Solids); therefore the trends of increase in total soluble solid content by addition of milk powder were expected. Increase in TSS up to 5 percent was also reported Deka et al., (2005).

The interaction of variety and milk powder additive was found to be non-significant. However, $\mathrm{V}_{1} \mathrm{~T}_{1}$ treatment combination possessed the maximum values of $80.32 \%$ total soluble solid in cheese as compared to others. Variety Lucknow-49 possessed the maximum values of 0.34 per cent acidity which was significantly superior over Apple guava but at par to Allahabad safeda. Moreover, Allahabad safeda and Apple guava were also found to be at par with each other. Similar findings were also reported by Jain and Nema (2007) these reported that the acidity of the product affected by the pulp of variety used for preparation of guava leather.

The decrease in acidity and increase in $\mathrm{pH}$ due to use of milk powder as additive for the preparation of cheese might be due to the change in constituents of cheese and decrease in concentration of ascorbic acid as well as 
phosphoric acids. Findings of Panades et al., (1993) also emphasized that the processing of guava pulp reduced the ascorbic acid concentration from $73.1 \%$ or 3.6 to $47.2 \%$ or 0.8 which had direct correlation with the reduction in acidity. Use of milk powder as additive in preparation of cheese with pulp of guava also changed the acidity per cent of the product and significantly reduced from 0.32 and $0.27 \%$. The pulp of guava variety Lucknow-49 without milk powder recorded higher value of acidity $(0.38 \%)$ over rest of the combination though the differences were not significant.

The ascorbic acid content in cheese prepared from pulp of Lucknow-49 was $37.52 \mathrm{mg} / 100$. It was significantly superior over both the varieties. Though, the variations between variety Allahabad safeda and Apple guava were not significant but the product of variety Allahabad safeda possessed numerically higher content of ascorbic acid $32.36 \mathrm{mg} / 100 \mathrm{~g}$. The highest ascorbic acid content in Lucknow-49 followed by Allahabad safeda, apple guava might be due to the varietal characters which were governed by the particular gene responsible for the character (Choudhary et al., 2008). The findings of Kumar et al., (2009) emphasized that the content of ascorbic acid also changed due to change in temperature which negatively reduced the content of ascorbic acid. The use of milk powder also had the significant effect on the ascorbic acid. The variations occurred in content of ascorbic acid might be due to the variations in the addition of milk powder Mahajan and Singh (2009).

\section{Organoleptic properties of prepared guava cheese}

Organoleptic properties like colour of cheese was undertaken after it preparation Table 3. The opinions were marked on the nine
Hedonic rating scales numerically. All the varieties were found to be significantly differing with each other. The prepared cheese from the variety Apple guava marked higher rank (7.90) in relation to the colour of cheese. Whereas, the cheese prepared from variety Allahabad safeda ranked 6.67 and comparatively proved significant inferior to others.

The milk powder markedly reduced the appearance of cheese over without milk powder. The maximum marks was obtained in hedonic scale was 7.83 under without milk powder which was significantly superior to be with milk powder (6.94). Interaction of variety and milk powder found to be significant and data showed that all the varieties without milk powder perform better in relation to contribute the colour whereas addition of milk powder markedly reduced the appearance of cheese. The maximum value of (8.50) was noted for variety Apple guava without milk powder whereas, the lowest rank (6.39) was observed in the treatment of Allahabad safeda with milk powder. Similar findings were noted by Mishra and Chopra (2006).

Guava varieties used for preparation of cheese had marked effect on taste of cheese. Guava variety Lucknow-49 and Apple guava showed similar taste and both of them proved significantly superior over Allahabad safeda. The addition of milk powder as additive during preparation of cheese had negative effect on the taste of the cheese and showed lower values markedly (7.93) over cheese prepared without milk product (8.30).

The interaction between varieties and value addition milk powder treatments was found to be non-significant with respect of taste of prepared guava cheese. Similar findings were noted by Prasad and Mali (2006). 
Varieties had significant effect on flavour cheese. The sensory score of flavour (8.0) was noted under Apple guava and proved significantly superior over Lucknow-49 and Allahabad safeda. The milk powder significantly reduced the flavour score of the cheese. The recorded values on flavour were 8.13 and 7.31 under without milk powder and with milk powder cheese product, respectively. Similar finding are noted by Badrie et al., (2005).

Texture score of the cheese changed significantly due to use of pulp of different guava varieties. The variety Lucknow-49 ranked first with the value of 7.52 and proved significantly superior over Allahabad safeda (7.05) and Apple guava (7.05). The effect of levels of addition of milk powder on texture score of cheese was significantly higher mean score of texture was recorded for product without use of milk powder. The interaction between variety and milk powder had significant effect on the texture score of the cheese. Among the varieties Lucknow-49 possessed higher value (8.55) over varieties used for preparation of cheese. However, varieties Allahabad safeda and Apple guava did not show any mark able difference for product of and without use of milk powder and recorded almost similar values of texture.

Thus, from the above findings it could be concluded that the variety Lucknow-49 proved to be a better over others and use of milk is not proved beneficial in improving to quality of cheese with respect to texture. Similar findings were noted by Walkunde et al., (2009). The prepared cheese from the Apple guava pulp found to be more acceptable and recorded the scale values of 7.81 followed by Lucknow- 49 with 7.78 scale values and both are significantly superior over to Allahabad safeda and showed non-significant difference to each other.
Guava cheese prepared without milk powder show higher overall acceptability as compared to product prepared with milk powder. The combined effect of varieties and milk powder found to bring out the change in the acceptability of the product. Cheese from all the three varieties without milk powder proved to be better over with milk powder. Variety Lucknow-49 recorded the higher point values of 8.32 closely followed by Apple guava (8.12) and it proved superior over rest of the treatments.

Thus, it is inferred that the variety Apple guava is better for the preparation of cheese in terms of acceptability. The addition of milk powder shows the decrease in store of colour, taste, flavour, texture and overall acceptability. The decrease in these parameters might be due to decrease in ascorbic acid content and simultaneously pectin degradation. These finding are similar with the findings of Patil et al., (2009) reported that the guava pulp treated with $5 \%$ percent sugar obtained maximum score for colour and flavour The addition of sugar up to $5 \%$ enhanced ascorbic acid retention as well as overall acceptance as compared to pulp with 7.5 and $10 \%$ added sugar.

\section{Acknowledgment}

The authors are grateful to the Department of Food and Nutrition Government M.H. College of Home Science \& Science for women, Jabalpur for providing me technical assistance and facilities to execute this study

\section{References}

Alizai, M. 2007. Studies on the preparation and composition of guava (Psidium guajava L.) Toffee and slab bars. Pak. J. Sci. Ind. Res., 50(4): 288-292.

Amerine, M.A., Pangborn, R.M. and Rossler, E.B. 1965. Principal of sensory 
evaluation of food. Academic press, New York.

AOAC 1992. Official method of analysis, Association of Official Analytical Chemists, Washington, D.C.

Ashaye, O.A., Babalola, S.O., Babalola, A.O., Aina, J.O. and Fasoyiro, S.B. 2005. Chemical and organoleptic characterization of pawpawand guava leather. World Journal of Agricultural Science, 1(1): 50-51.

Badrie, $\mathrm{N}$ and Cary Anderson 2005. Physicochemical quality and consumer acceptance of guava wines. J. food science, 42(3): 223-226.

Chawala, P., Ghais and Sandhu, S.K. 2005. Studies on the nutritional and organoleptic characteristics of carrot pickle during storage. J. Food Science, 42(4): 358-360

Choudhary, M.L., Dikshit, S.N., Shukla, Neeraj and Saxena, R.R. 2008. Evaluation of guava (Psidium guajava L.) varieties and standardization of recipe for nectar preparation. Journal of Horticultural Science, 3(2): 161-163.

Deka, B.C., Sethi, V. and Saika, A. 2005. Changes on mango-pineapple spiced beverages during storage. Indian $\mathrm{J}$. Horti., 62(1): 71-75.

Dubey, P.S., Hoda, M.N., Singh, Jayant and Singh, S.K. 2009. Studies on physicochemical properties of rainy season guava fruits. Indian J. Horti., 66(4): 522-523.

Durmaz, H. Tarakei, Z, Sagun E and Sancak, $\mathrm{H}$ 2006. Effect of ripening time on mineral Contents of herby Cheese. Journal of Animal and Veterinary Advances, 5(12): 1050-1052.

Gupta, G.K., Jagbir Chahal and Arora, Deeksha 2011. Psidium guajava a great therapeutic potential. Journal of Pharmacy Research, 4(1): 42-46.

Harmanan, S.W., Bains, G.S. and Singh, A. 2005. Studies on the processing of pink and white fleshed guava varieties for pulp. Punjab Horti. J., 20(1-2): 179-189.

Jain, P.K. and Asati, V.K. 2004. Evaluation of guava cultivars for pulp preparation. Journal of Food Science and Technology, 41(6): 684-686.

Jain, P.K. and Nema, P.K. 2007. Processing of pulp of various cultivars of guava (Psidium guajava L.) for leather production. Agricultural Engineering International: CIGR Journal, 9 42-46

Kalloo, G., Reddy, B.M.C., Tondon, D.K., Singh, M.D., Pandey, B.K. and Verma, Anil 2005. Post-harvest management and value addition in horticultural crops. Published by Director Central Institute for subtropical Horticulture, Rehmankhera Kakori, Lucknow, pp. 1719

Khattak, J.Z.K., Kha, S. Matizur Rehman, Raza, S., Ullah, J. and Khattak, H.Z.K. 1997. Comparative study of physical and chemical characteristics of five guava cultivars. Sarhad Journal of Agriculture, 15(4): 287-290.

Kumar, Suresh, Sagar, V.R. and Singh Uadal 2009. Effect of ripening stages on osmo-dehydrated guava slices. J. Food Sci. Technol., 45(6): 546-548.

Lal, G. Siddappa, G.S. and Tondon, G.L. 1998. Preservation of fruits and vegetables. ICAR, New Delhi.

Mahajan, B.V.C. and Singh Gangandeep (2009). Effect of 1methylcychlopropene (1-MCP) on storage life and quality of winter guava. J. Food Sci. Technol., 45(6): 537-539.

Mishra, Haridwar and Chopra, C.S. 2006. Processing and storage studies on Bael fruit products: Crush and jam. Beverage and Food World, pp. 44-45.

Panades. G., Tejo. T, Sevillano, E. and Ravelo, E. 1993. Influence of aseptic processing and tank storage on quality of guava pulp. Alimentaria. (No. 242): 75-77. 
Pandey, K.K., Sharma, A.B. and Patel, M.P. 1997. The varietal evaluation of guava (Psidium guajava L.). Ad. Plant Sci., 10(1): 157-163.

Panshe, V.G. and Sukhatme, P.V. 1963. Statistical methods for agriculture worker, ICAR publication, New Delhi.

Patil, A.P., Chavan, K.D. and Bhosale, D.N. 2009. Influence of addition of guava pulp and sugar an sensory quality of guava yoghurt. Journal of Dairying Foods and Home Science, 28(2): 95100.

Prasad, R.N. and Mali, P.C. 2006. Changes on physico-chemical characteristics of Ber jam during storage. Indian J. Hort., 63(1): 86-87.

Singh, M. 1988. Performance of some cultivars of guava (Psidium guajava $L$.) with special reference to their commercial significance in the central Gangatic Plains. Punjab Hort. J., 28(1and2): 50-55.

Singh, S, Godara, A.K. and Bhatia, S.K. (2003). Effect of different packaging materials on the ethylene Evolution rate in guava. Haryana J. Horti. Sci. 32(3and4): 203-205.

Torrezan, R., Jardine, J.G. and Vitali, A. de A. 1999. Effect of solutes and acid addition to guava pulp. Ciencia and Technologia de Alimentos, 19(1): 4345.

Walkunde, T.R., Kamble, D.K. and Pawar, B.K. 2009. Sensory quality of yoghurt from cow milk by utilizing guava fruit. Asian Journal of Animal Science, 3(2): 99-102.

\section{How to cite this article:}

Rashmi Shukla, Y.K. Shukla and Smita Pathak. 2018. Standardization and Preparation of Guava Cheese from Different Cultivars. Int.J.Curr.Microbiol.App.Sci. 7(03): 583-595. doi: https://doi.org/10.20546/ijcmas.2018.703.069 